\title{
CYP2C18 Gene
}

National Cancer Institute

\section{Source}

National Cancer Institute. CYP2C18 Gene. NCI Thesaurus. Code C26513.

This gene plays a role in the metabolism of fatty acids, tryptophan, drugs and xenobiotics. 